\title{
Ten Years Later: Lessons for DSGE Builders and Czech Policy Makers
}

\section{Aleš Michl ${ }^{1}$}

\begin{abstract}
We show an example of a small open economy - the Czech Republic where the fiscal restriction was put in place between 2010 and 2013 in a negative output gap and zero lower bound on nominal interest rates. According to our results, such fiscal policy seems to have been mistaken, as the restriction may apparently have caused a second recession in the Czech Republic in 2012/2013 (after the global recession in 2008/2009). Instead of the dynamic stochastic general equilibrium approach (DSGE), we applied a tractable static deterministic partial equilibrium approach using the IS-LM framework. We derived mathematically from the IS-LM model that expansionary fiscal policy acting via higher government investment can be an appropriate tool for reacting to a crisis in the very short run when interest rates hit the zero lower bound. Expansionary fiscal policy after the 2008/2009 crisis would probably have led to faster stabilisation of the Czech economy. We simulate a potential increase in government investment of $8 \%$ yearly between 2011 and 2013. This would have added 0.4 pp to GDP growth and increased the inflation rate by about $0.5 \mathrm{pp}$. Hence, the inflation outlook in 2013 would not have been negative and would consequently have led to less pressure for monetary policy expansion using unconventional interventions against the Czech koruna.
\end{abstract}

Keywords: IS-LM model, DSGE, zero lower bound, fiscal policy, monetary policy

JEL Classification: E12, E41, E44, E62

Received: 9 April 2018 / Accepted: 26 July 2019/Sent for Publication: 9 September 2019

\section{Introduction and review of literature}

New-Keynesianism has a problem. Most contemporary dynamic stochastic general equilibrium (DSGE) models are mostly resilient to the Lucas critique (Lucas, 1976), but questions arise related to their usefulness in practice - why were they unable to signal the growing interconnectedness and fragility of economies around the world with regard to problems in the financial sector before 2008 ?

Teams of experts from both the Czech National Bank (CNB) and the Czech Ministry of Finance mainly use the DSGE approach to model the Czech economy. The CNB's ap-

\footnotetext{
${ }^{1}$ Ph.D. student at the Faculty of Finance and Accounting, University of Economics, Prague, Czech Republic, ales.michl@gmail.com.
} 
proach is described in Beneš et al. (2005), Anderle et al. (2009) and in many other CNB Working Papers. The less comprehensive DSGE approach of the Czech Ministry of Finance is summed up in Aliyev et al. (2014). Besides the CNB, the other main examples of central banks basing their decisions heavily on DSGE models are Sveriges Riksbank and the Bank of England. Other central banks use DSGE models to a lesser degree. In the European Central Bank, an in-house DSGE model serves as a tool to decompose the shocks derived from the baseline projection, which is constructed from many models and expert judgement. The Federal Reserve does not use DSGE as its main tool, although the New York Fed, for example, employs one for macro predictions (Justiniano et al., 2017). Still, New-Keynesian DSGE is the only truly ubiquitous modelling framework in central banking; no other theoretical concept is so widely used and applied.

Ten years on from 2008/2009, we have an opportunity to discuss the potential lessons for DSGE builders and Czech policy makers. Overall, Williams (2018) provides an insightful summary of the discussion on the practical usefulness of DSGE models and notes that while they are helpful in many cases, they also have important limitations: notably the assumption that all shocks are transitory and that important parameters are stable. $^{2}$ As a reflection of the limitations of the current macroeconomic modelling framework, an entire double issue of Oxford Review of Economic Policy (2018) was devoted to this topic. In this issue, Blanchard (2018) sums up that there is a widespread consensus that DSGE models failed before and during the crisis, but little agreement on what alternative modelling framework could deliver better results.

One reason for the problematic forecasting performance of DSGE models is that they have historically ignored money aggregates and the financial sector, despite the complexity of the models. If the next recession (or even crisis) is caused by a problem peculiar to the asset markets, analogously to the last three recessions in the US, DSGE models will again be of little use in warning against these downturns. As DeGrauwe and Gros (2009) point out, in DSGE models, financial crises, bubbles, and crashes cannot occur - agents are perfectly informed and rational, ${ }^{3}$ and prices always reflect the underlying fundamentals. And because DSGE models do not work with monetary aggregates, they cannot directly evaluate the impacts of a resulting decrease in the growth rate of M3 (or corporate loans/a deleveraging process) and other measures; these effects have to be incorporated on an ad-hoc basis by expert judgement.

\footnotetext{
${ }^{2}$ One of the key parameters is the natural real interest rate. Rachel and Summers (2019) demonstrated that neutral real interest rates would have declined by far more than what has been observed in the industrial world and would in all likelihood be significantly negative but for offsetting fiscal policies over the last generation. They conclude that the "private sector neutral real rate" may have declined by as much as 700 basis points since the 1970 s.

${ }^{3}$ This is also one of the reasons why in macroeconomic modelling there is currently a lot of interest in bounded rationality, learning mechanisms, hand-to-mouth consumption behaviour, rational inattention and so on. These aspects are progressive ways forward for the development of DSGE models.
} 
DSGE models also have trouble capturing changes in economic agents' expectations that are not related to fundamentals (and, in general, all psychological effects), for instance when there is a surprising and sudden increase in pessimism regarding economic prospects ${ }^{4}$. But, as eloquently put in the defence of DSGE models by Brůha and Hlédik (2018), there currently exists no model, DSGE or other, that can predict a financial crisis and then correctly quantify its effect on economic growth. If such a model existed or was developed in the future, the likelihood of the occurrence of financial crises would decrease, because policy authorities would have the opportunity to act in advance and prevent the crisis from happening - but then such a model would contradict itself, which again stems from the logic of the Lucas critique (Brůha and Hlédik, 2018).

The omission of the financial sector might be the reason why DSGE models are hardly ever used in the private sector - no major investment bank or hedge fund uses one. In other words, there is currently no known DSGE model application capable of making money for investors. Of course, by their nature, central banks do not aim to turn a profit, at least not primarily, ${ }^{5}$ but rather they endeavour to model the path of the economy consistent with their own decisions on interest rates and other monetary policy instruments. However, we will leave the further development of DSGE models to econometricians and business cycle theoreticians and focus in this article on the policy lessons of the 2008/2009 financial crisis, when the zero lower bound (ZLB) was reached and economic policy recommendations had to be issued.

The problem was that as major central banks lowered their policy rates to zero after 2008/2009, their DSGE models (but also semi-structural models and simple models based on the Taylor rule) started to recommend significantly negative interest rates. The main forecasting model of the Czech National Bank signalled a need for the interest rate to decrease to $-1 \%$ in 2013. Passing such negative rates to depositors, it would become profitable for savers to withdraw their funds from Czech commercial banks and hoard cash, which would, in turn, endanger the financial stability of the entire country. Because such deeply negative rates were not reasonable and the inflation outlook was negative, the Czech National Bank switched to unconventional monetary policy and started to intervene against its own currency. ${ }^{6}$

To understand the economic situation, it should be added that the main cause of the first recession in the Czech Republic in 2009 was not the Czech financial sector, but a dramatic decline in external demand. ${ }^{7}$ However, the Czech Republic also experienced a

\footnotetext{
${ }^{4}$ Although building on the work of Bernanke et al. (1998) the new generation of model attributes the Great Recession to a financial shock associated with a massive spike in credit spreads (Christiano et al., 2014; Justiniano et al., 2017).

${ }^{5}$ On that front we would argue, however, that the income statement of the central bank matters as well. One possible economic point of view is that the potential cumulative loss of the central bank is part of the general public debt.

${ }^{6}$ See Franta et al. (2011) for the explanation of using exchange rate as an instrument at zero interest rates.

${ }^{7}$ Ryšánek et al. (2011) confirm this conclusion using an analysis based on a DSGE model with financial frictions. In defence of the CNB's DSGE model, we can add here that the primary source of prediction error was wrongly estimated external variables, which are exogenous to the
} 
second recession in 2012/2013 when the GDP of its largest trading partner Germany was rising modestly. While monetary policy was expansionary, what role should fiscal policy have played, and what role did it play, in the Czech Republic? Here we get to the nub of our contribution. Our reasoning gives rise to two difficult questions:

(1) What is the policy recommendation when the zero lower bound is reached?

(2) What are the lessons of the policy reaction in the Czech Republic after $2008 / 2009$ ?

\section{What is the policy recommendation when the zero lower bound is reached?}

In a prototype DSGE model, there is both ignorance of the zero lower bound (ZLB) on the central bank's interest rate $^{8}$ and an assumption of Ricardian equivalence. This means that fiscal policy has no long-term effect on GDP. In most DSGE models, however, Ricardian equivalence does not hold in the short run. This is due to various rigidities in the model, so a fiscal impulse has a temporarily positive effect on output and inflation. Therefore, even in a DSGE model, fiscal policy can stimulate the economy, although only in the short run. On the other hand, the nature of DSGE models requires the fiscal authority to be sustainable in the long run (i.e. government debt cannot explode). In other words, DSGE models with fiscal policy enable economists to model the impact of short-term fiscal shocks and the short-term effects of stabilisation policies, ${ }^{9}$ but not to fully model the impacts of "fiscal crises" when the private sector's trust in fiscal sustainability is compromised, such as those that occurred in Argentina and Greece.

To answer the first question, it is important that New-Keynesian DSGE models are general equilibrium models based on the interactions between market actors, that is, on the same principles explored - albeit in a simpler and more stylised modelling language - by Keynes and Hicks. In the long run, Ricardian equivalence holds sway: expansionary fiscal policy now means restrictive fiscal policy in the future. But in the short run, the DSGE approach can model well Keynes' original insight that in good times one has

CNB's model.

${ }^{8}$ It should be stressed that in response to the crisis, model builders tried to develop fast computational tools for solving DSGE models under the ZLB (e.g. Brůha, 2015).

${ }^{9}$ There are two ways of overcoming the Ricardian equivalence in DSGE models. First, because of real and nominal frictions, prices and quantities do not immediately adjust to the levels desired by rational optimising agents. Therefore, fiscal policy has effects before the quantities adjust to their equilibrium levels. The second, and more straightforward, way of enabling fiscal policy to have an effect in a DSGE model is to assume that a part of the population follows a "rule of thumb" and consumes their entire income (this is also the path chosen by the CNB for the update of its core forecasting model; the new version, g3+, will assume that $30 \%$ of the population follow the consumption rule of thumb). Rule-of-thumb consumers (Campbell and Mankiw, 1989) do not behave according to Friedman's permanent income hypothesis, but are similar to typical consumers from Keynesian models: they spend a fraction of their current income (in most DSGE models, all of it). There are two basic explanations for the departure from the permanent income hypothesis: the households in question may be myopic or they may face binding liquidity constraints (they may be unable to borrow money in order to smooth consumption). For this solution to work, the share of rule-of-thumb consumers must be sizeable: for example, Gali et al. (2007) show that with the share of rule-of-thumb consumers below $25 \%$, the fiscal multiplier is still negative. 
to save and in bad times one has to spend. Modelling such a situation may be simpler than we often admit: the "dynamic stochastic general equilibrium" framework does not have to suit each and every problem; sometimes "static deterministic partial equilibrium", which we can better describe and analyse, will do (and may even work better). With this in mind, we offer the IS-LM model applied to the ZLB problem for consideration.

We realise how old and elementary the 1937 IS-LM model ${ }^{10}$ looks today and how anachronistic it seems to use it to discuss the 2008/2009 financial crisis. It seemed the IS-LM model itself would fall into oblivion, to be used only by theoreticians to describe the fundamental linkages in the economy. ${ }^{11}$ This was linked with the fact that before 2008/2009, most economists believed that the zero lower bound was unlikely to be reached and that the earlier Japanese experience was a special case that would not be repeated in other countries.

The problem became more relevant as major central banks lowered their policy rates to zero after the 2008/2009 crisis. The IS-LM model ceased to serve as a mere teaching aid for undergraduate macroeconomics courses. The US Federal Reserve issued an article on the ZLB as early as December 2008 (Madigan et al., 2008). Koenig (2011) described the application of the IS-LM model to the ZLB problem. Krugman (2011) then published his popular "IS-LMentary" article referring to the foundations of the model. Later he added that many incremental changes to the DSGE model had been suggested, but without a single big new idea; this was because the policy responses based on IS-LM were appropriate (Krugman, 2018). Articles by Federal Reserve staff are again coming out in the economic literature. For example, Kiley and Roberts (2017) note that the ZLB will continue to cause monetary policy problems in the future, an issue echoed by Mertens and Williams (2019). So, even Fed experts admit that DSGE cannot do it all and we also need some simple, partial equilibrium models.

We will thus apply the IS-LM model to mathematically derive and identify meaningful economic policy recommendations for periods of zero interest rates.

Let's start with the well-known equation for the IS curve in a closed economy:

$$
Y=C\left(Y^{\prime}, T\right)+I(Y, i)+G
$$

Variable $Y$ on the left-hand side of the equation corresponds in the real economy to gross domestic product (GDP), whereas the $Y^{\prime}$ in parenthesis in the consumption function should correspond to aggregate disposable income or the net income of households. However, let's simplify matters by not distinguishing between the two variables and by

\footnotetext{
${ }^{10}$ Hicks $(1937,1976,1980)$, Hansen (1949), Tobin (1981).

${ }^{11}$ Colander (2003). Moreover, money M disappeared from the model - the money supply was replaced by the interest rate as the instrument of central banks. Romer (2000) completely abandoned the LM curve and discussed an IS-MP model, where MP stands for monetary policy. A further development was the IS-PC-MR model, where PC denotes the Phillips curve and MR the monetary rule, for example the Taylor rule (TR), and money - or an explicit LM function - is thus dropped from the model (for the textbook IS-TR model see Burda and Wyplosz, 2013).
} 
identifying them both as $Y$. Variable $G$ covers both government consumption and government investment, and $I$ represents private investment by firms and households. $Y$ in the functional relation for $I$ is taken to be a proxy for the adaptive expectations of private agents.

The total expenditure of households and firms, i.e. private expenditure, both consumption and investment, is denoted as . The following then holds:

$$
E=C(Y, T)+I(Y, i)=E(Y, i, T)
$$

where the relationship between consumption and income is positive, whereas those between consumption and the interest rate and between consumption and the tax burden are negative, i.e. partial derivatives $E_{Y}>0 \wedge 0 \prec E_{Y} \prec 1, E_{i} \prec 0, E_{T} \prec 0$.

For income $Y$ at the aggregate level in a closed economy, we can write:

$$
Y=E(Y, i, T)+G
$$

This gives us the equation for the IS curve in a closed economy. This version is clearer than equation (6) in terms of notation for further processing and derivation. It clearly separates private consumption and investment on the one hand and government policy on the other, but it does not change the outcome in any way.

The money market is represented by demand for money $L(Y, i)$, i.e. partial derivatives $L_{Y}>0, L_{i} \prec 0$. For balance on the money market, $M=L$, we can hence define the LM curve as:

$$
M=L(Y, i) \text {. }
$$

The important aspect for macroeconomic policy is how monetary and fiscal policy, i.e. change in $M, G, T$, affects $Y$ when the economy is at the ZLB. We will therefore now derive the system of two equations (3) and (4) with multiple unknowns, solve using a matrix $^{12}$ and discuss the situation where $L_{i}$ changes from $L_{i} \prec 0$ to $L_{i} \rightarrow \infty{ }^{13}$

We will take the total derivative, which, unlike the partial derivative, takes into account the dependencies between the variables:

$$
\begin{aligned}
& \mathrm{dY}=E_{Y} d Y+E_{i} d i+E_{T} d T+d G \\
& \mathrm{dM}=L_{Y} d Y+L_{i} d i .
\end{aligned}
$$

We can modify this system by putting the endogenous variables $d i$ and $d Y$ on the lefthand side of the equation and the exogenous variables $T, G, M$ on the right-hand side:

\footnotetext{
${ }^{12}$ A similar approach to mathematising the model can be found in Carter (2001) and Kennedy (2011).

${ }^{13}$ The assumption that the economy faces the zero lower bound and it falls into a deflationary spiral. Speculative demand for money can then completely swallow up the growth in supply, as may have been the case after 2008/2009, thus $L_{i} \rightarrow \infty$ (the liquidity trap concept, e.g. Robertson, 1936).
} 


$$
\begin{aligned}
& \left(1-E_{Y}\right) d Y-E_{i} d i=E_{T} d T+d G \\
& L_{Y} d Y+L_{i} d i=\mathrm{dM}
\end{aligned}
$$

We can then convert the system into a matrix form. We define a total of three matrices of the form $A x=b$, one for the coefficients $(A)$, one for the endogenous variables $(x)$ and one for the right-hand side $(b)$, where we have the exogenous variables, i.e. the fiscal and monetary policy instruments $T, G, M$ :

$$
\left[\begin{array}{cc}
1-E_{Y} & -E_{i} \\
L_{Y} & L_{i}
\end{array}\right] \cdot\left[\begin{array}{c}
d Y \\
d i
\end{array}\right]=\left[\begin{array}{cc}
E_{T} d T & d G \\
d M &
\end{array}\right]
$$

\section{Monetary policy}

Let's start by deriving the impact of monetary policy. We are interested in the effect of $d M$ on $d Y$. We will assume that $d G=d T=0$ and later add $L_{i} \rightarrow \infty$. The system of equations written in matrix form as $A x=b$ takes the form:

$$
\left[\begin{array}{cc}
1-E_{Y} & -E_{i} \\
L_{Y} & L_{i}
\end{array}\right] \cdot\left[\begin{array}{c}
d Y \\
d i
\end{array}\right]=\left[\begin{array}{c}
0 \\
d M
\end{array}\right]
$$

We calculate the determinant of matrix $A$ :

$$
\mathrm{D}=\left(1-E_{Y}\right) L_{i}+L_{Y} E_{i} \prec 0 \neq 0
$$

The determinant is smaller than zero, because $L_{Y}>0, L_{i} \prec 0,0 \prec E_{Y} \prec 1, E_{i} \prec 0$.

We now invoke Cramer's rule, which says that if the determinant of matrix $A$ from system $A x=b$ is nonzero, the system has a unique solution equal to the determinant of matrix $A_{x}$ divided by the determinant of matrix $A$.

Let's derive matrix $A_{x}$ from the system $A x=b$ :

$$
\left[\begin{array}{cc}
0 & -E_{i} \\
d M & L_{i}
\end{array}\right]
$$

The determinant of matrix $A_{x}$ is:

$$
D_{x}=d M E_{i}
$$

The solution is $D_{x}$ divided by $D$. We transpose $d M$ directly to the left-hand side:

$$
\mathrm{dY} / \mathrm{dM}=E_{i} /\left(\left(1-E_{Y}\right) L_{i}+L_{Y} E_{i}\right)
$$

Then, if $L_{i}$ is changed from $L_{i} \prec 0$ to $L_{i} \rightarrow \infty$ :

$$
\lim _{L_{i} \rightarrow \infty}(d Y / d M)=\lim _{L_{i} \rightarrow \infty}\left(E_{i} /\left(\left(1-E_{Y}\right) L_{i}+L_{Y} E_{i}\right)\right)=\left[\frac{\text { constant }}{\infty}\right]=0
$$

In the model with a zero interest rate, monetary policy is ineffective - an increase in money supply $M$ does not lead to a change in $Y$. 


\section{Fiscal policy}

This time we assume that $d M=d T=0$ and we are interested in the effect of $d G$ on $d Y$, i.e. the government spending fiscal multiplier.

The system of equations in the form $A x=b$ this time takes the form:

$$
\left[\begin{array}{cc}
1-E_{Y} & -E_{i} \\
L_{Y} & L_{i}
\end{array}\right] \cdot\left[\begin{array}{c}
d Y \\
d i
\end{array}\right]=\left[\begin{array}{c}
d G \\
0
\end{array}\right]
$$

Matrix $A$ is the same, so the determinant is also the same

$$
\mathrm{D}=\left(1-E_{Y}\right) L_{i}+L_{Y} E_{i} \prec 0 \neq 0
$$

We now invoke Cramer's rule again.

Matrix $A_{x}$ is now:

$$
\left[\begin{array}{cc}
d G & -E_{i} \\
0 & L_{i}
\end{array}\right]
$$

The determinant of matrix $A_{x}$ is:

$$
D_{x}=d G L_{i}
$$

The solution is $D_{x}$ divided by $D$. We transpose $d G$ directly to the left-hand side:

$$
d Y / d G=L_{i} /\left(\left(1-E_{Y}\right) L_{i}+L_{Y} E_{i}\right)
$$

Then, if $L_{i}$ is changed from $L_{i} \prec 0$ to $L_{i} \rightarrow \infty$ :

$$
\begin{aligned}
& \operatorname{Lim}_{L_{i} \rightarrow \infty}(d Y / d G)= \\
& \lim _{L_{i} \rightarrow \infty}\left(\frac{L_{i}}{\left(1-E_{Y}\right) L_{i}+L_{Y} E_{i}}\right)=\lim _{L_{i} \rightarrow \infty}\left(\frac{L_{i}}{L_{i}\left(1-E_{Y}\right)+\frac{L_{Y} E_{i}}{L_{i}}}\right)=\lim _{L_{i} \rightarrow \infty}\left(\frac{1}{\left(1-E_{Y}\right)+\frac{L_{Y} E_{i}}{L_{i}}}\right)=\left[\frac{1}{1-E_{Y}+0}\right]= \\
& 1 /\left(1-E_{Y}\right),
\end{aligned}
$$

and simultaneously

$$
1 /\left(1-E_{Y}\right)>0,
$$

because $0 \prec E_{Y} \prec 1$.

In the model with a zero interest rate, fiscal policy is effective - an increase in government expenditure leads to a change in $Y$.

Analogously, assuming $d M=d G=0$, we will derive the fiscal multiplier for a tax change, i.e. the impact of $d T$ on $d Y$ (the procedure is analogous, so we will write the result directly):

$$
d Y / d T=E_{T} /\left(1-E_{Y}\right)
$$

To sum up, the fiscal multipliers for $G$ and $T$ are therefore $1 /\left(1-E_{Y}\right)$ and $E_{T} /(1-$ $\left.E_{Y}\right)$.

For our subsequent considerations, it is important to know which multiplier will be higher. Let's, therefore, try to prove that: 


$$
1 /\left(1-E_{Y}\right)>E_{T} /\left(1-E_{Y}\right),
$$

Assuming that $E_{Y} \prec 1$ (satisfied), the inequality applies if

$$
1>E_{T} \text {, }
$$

which holds, because $E_{T} \prec 0$.

To sum up, at the zero lower bound, an increase in $G$ has a greater effect on final output than an equivalent reduction in taxes $T$. The economic explanation is that the government spending multiplier affects GDP directly, whereas a tax change influences GDP indirectly by changing disposable income, with households saving part of the funds they gain from the tax cut. In normal circumstances, a government spending hike or a tax cut is accompanied by an initial increase in $Y$, but also by an increase in the market interest rate and in turn by a fall in private investment ("crowding out", which then pushes down $Y$ ). But since we are describing a situation where $L_{i} \rightarrow \infty \wedge i=0$, investment will not be crowded out (LM is horizontal, $L_{i} \rightarrow \infty$, the interest rate does not rise). By contrast, an increase in $M$ has no effect on $Y$ (LM is horizontal). Under these conditions, pursuing expansionary fiscal policy by boosting government investment is the best option.

The constraints on fiscal expansion are both the level of the private sector's trust in fiscal sustainability and that it is subject to Ricardian equivalence in the long term. However, as we mentioned, research indicates that Ricardian equivalence may not hold fully in a short-term crisis. For example, Parker et al. (2013) found that US consumers spent a large part of the fiscal transfers they received after the 2008/2009 crisis. This is inconsistent with Ricardian equivalence in the strict sense. Put in another way, when GDP is at or above its potential, fiscal expansion leads to the crowding out of private investment, higher inflation and/or a current account deficit (IMF, MIT, 2014).

\section{What are the lessons of the policy reaction in the Czech Republic after 2008/2009?}

At this point, we turn to evaluate Czech fiscal policy after the 2008/2009 crisis. Did it follow the recommendations that stem from the maths we present in this paper? For the evaluation, we will use the methodology of Ambriško et al. (2012). They documented fiscal discretion in the Czech Republic in 2001-2011 based on macroeconomic data and on their own extensive survey of tax legislation changes. No such survey had previously been conducted for the Czech economy. We extend their time series to 2014 and, because of data revisions, we also update the entries for previous years. Ambriško et al. (2012) acknowledged that the empirical identification of fiscal discretion and the analysis of its impacts are complicated by the limited length of the time series, by incomplete information and by the presence of structural breaks. Therefore it makes sense to use two methods to evaluate fiscal discretion from different analytical angles: ${ }^{14}$

\footnotetext{
${ }^{14}$ For these methods for evaluating fiscal discretion in detail see Appendix A in Ambriško et al. (2012). We would also like to thank Czech National Bank researcher R. Ambriško for providing details about past fiscal discretion in the Czech Republic.
} 
(i) The bottom-up (direct) method summarises the estimated effects of individual discretionary government revenue and expenditure measures on real GDP growth.For example from the collection of a comprehensive database of tax legislation changes and expenditure discretion. We will call this method the fiscal impulse.

(ii) The top-down (indirect) method measures fiscal discretion by the annual change in the ratio of the structural government budget balance to GDP. We will call this method the fiscal stance.

The results are summarised in Tables 1 and 2 .

Table 1. Czech Republic: Fiscal impulse ( "bottom-up" method, minus = fiscal restriction)

\begin{tabular}{|l|c|c|c|c|c|c|c|c|}
\hline & 2007 & 2008 & 2009 & 2010 & 2011 & 2012 & 2013 & 2014 \\
\hline $\begin{array}{l}\text { Output gap - production } \\
\text { function (\% of potential } \\
\text { output) }\end{array}$ & 3.2 & 2.2 & -1.5 & -0.8 & 0.8 & -0.3 & -1.9 & -1.3 \\
\hline $\begin{array}{l}\text { Fiscal impulse (contribu- } \\
\text { tions to GDP growth in pp) }\end{array}$ & -0.4 & 0.8 & 1.3 & -0.7 & -0.5 & -0.3 & -1.0 & 0.3 \\
\hline
\end{tabular}

Source: Czech National Bank, methodology: Ambriško et al. (2012)

Table 2. Czech Republic: Fiscal stance ("top-down" method, plus = fiscal restriction)

\begin{tabular}{|l|c|c|c|c|c|c|c|c|}
\hline & 2007 & 2008 & 2009 & 2010 & 2011 & 2012 & 2013 & 2014 \\
\hline $\begin{array}{l}\text { Fiscal stance (EC method- } \\
\text { ology, pp) }\end{array}$ & 1.1 & -1.2 & -2.6 & 1.5 & 1.0 & 0.4 & 1.7 & -0.3 \\
\hline $\begin{array}{l}\text { Fiscal stance (ESCB meth- } \\
\text { odology, pp) }\end{array}$ & 0.8 & -1.4 & -2.3 & 1.6 & 1.5 & 0.7 & 1.6 & -0.3 \\
\hline
\end{tabular}

Note: The method labelled EC assumes that public finances are sensitive to changes in the output gap. The method labelled ESCB links the individual components of government revenues and expenditure to their relevant macroeconomic bases and the sum of these components is assumed to be the total effect of the economic cycle.

Source: Czech National Bank, methodology: Ambriško et al. (2012)

According to both the fiscal impulse methodology (Table 1) and the fiscal stance methodology (Table 2), there was a fiscal restriction in the Czech Republic in 2007 and 2010-2013. The reaction of fiscal policy in the period after the 2008/2009 crisis was thus precisely the opposite of the IS-LM model recommendation.

Table 3 structures the fiscal impulse according to estimated impact on private consumption, private investment, domestic government investment, and EU-funded government investment. We can see from Table 3 that in 2010-2013 fiscal restriction had the strongest negative effect on household consumption because it was based on tax hikes and the second-strongest effect on government investment. ${ }^{15}$

${ }^{15}$ For example, Czech government measures in 2012 and 2013: In 2012, the restriction was driv- 
Table 3: Czech Republic: Fiscal impulse structure ("bottom-up" method, minus = fiscal restriction)

\begin{tabular}{|r|c|c|c|c|c|c|c|c|}
\hline & 2007 & 2008 & 2009 & 2010 & 2011 & 2012 & 2013 & 2014 \\
\hline $\begin{array}{r}\text { Fiscal impulse (contribu- } \\
\text { tions to GDP growth in pp) }\end{array}$ & -0.4 & 0.8 & 1.3 & -0.7 & -0.5 & -0.3 & -1.0 & 0.3 \\
\hline of which impact through: & & & & & & & & \\
\hline Private consumption & -0.3 & 0.4 & 0.4 & -0.3 & -0.3 & -0.1 & -0.7 & 0.1 \\
\hline Private investment & 0.0 & 0.1 & 0.3 & 0.1 & 0.0 & 0.0 & 0.0 & 0.0 \\
\hline Government investment & -0.1 & 0.1 & 0.2 & -0.4 & -0.2 & 0.1 & -0.3 & 0.1 \\
\hline $\begin{array}{r}\text { EU-funded government } \\
\text { investment }\end{array}$ & 0.0 & 0.2 & 0.4 & 0.0 & 0.0 & -0.2 & 0.0 & 0.2 \\
\hline
\end{tabular}

Source: Czech National Bank

As shown in Table 4, in the period 2012-2013 the Czech economy was at the zero lower bound (ZLB) and had a deeply negative output gap. The debt level was no higher than $45 \%$ of GDP and the government yield spread with respect to Germany - our proxy for assessing government debt risk (or for assessing the level of private sector's trust in fiscal sustainability ${ }^{16}$ ) - was falling. When the ZLB is binding, and the inflation outlook is negative, the typical DSGE model will drive the central bank's policy rate into negative territory. As it was mentioned, the main forecasting model of the Czech National Bank signalled a need to lower the interest rate to $-1 \%$ in late 2013 . As explained above, because such deeply negative rates were not reasonable and fiscal policy was restrictive with an outlook of austerity, the Czech National Bank switched to unconventional monetary policy and started to intervene against its own currency.

en by measures totalling CZK 19 billion on the tax revenue side (an increase in the reduced VAT rate from $10 \%$ to $14 \%$, an increase in taxation of lotteries and gambling, a rise in excise duty on tobacco and an increase in the number of persons with mandatory sickness insurance). In addition, the non-wage component of government consumption decreased relatively significantly year on year (restriction estimated at CZK -23.3 billion) and investment also dropped (CZK -14.4 billion). In 2013, further tax revenue measures were adopted (including a hike in both VAT rates of $1 \mathrm{pp}$, the introduction of a solidarity tax for personal income tax, a reduction of the flat-rate expenditure allowance for the self-employed and the scrapping of the personal income tax discount for working pensioners; total CZK 33 billion). Restrictive measures totalling around CZK 15 billion were also introduced on the expenditure side of public budgets (the most significant in terms of impact being a smaller increase in pensions and a public sector pay freeze). There was also a drop in government investment with an estimated restriction of around CZK 18 billion.

${ }^{16}$ There is no consensus about the appropriate criterion to be used for fiscal sustainability. Academics tend to use government's inter-temporal budget constraint, we rather use more straightforward market indicator of government yield spread to the benchmark economy (an alternative could be the CDS spread). 
Table 4: The Czech Republic: Macroeconomic variables

\begin{tabular}{|c|c|c|c|c|c|c|c|c|c|}
\hline & $\begin{array}{l}\text { Output } \\
\text { gap - } \\
\text { produc- } \\
\text { tion } \\
\text { func- } \\
\text { tion (\% } \\
\text { of } \\
\text { poten- } \\
\text { tial } \\
\text { output) }\end{array}$ & $\begin{array}{l}\text { Fiscal } \\
\text { im- } \\
\text { pulse } \\
\text { (con- } \\
\text { tribu- } \\
\text { tions to } \\
\text { GDP } \\
\text { growth } \\
\text { in pp) }\end{array}$ & $\begin{array}{c}\text { Govern } \\
\text { ern- } \\
\text { ment } \\
\text { debt (\% } \\
\text { GDP) }\end{array}$ & $\begin{array}{c}\mathrm{CZ} \\
\text { govern- } \\
\text { ern- } \\
\text { ment } \\
\text { bond } \\
\text { yield } \\
5 \mathrm{Y}(\%)\end{array}$ & $\begin{array}{c}\text { Debt } \\
\text { risk: } \\
5 Y \\
\text { Gov. } \\
\text { yield } \\
\text { spread } \\
\text { vs } \\
\text { Ger- } \\
\text { many } \\
\text { (pp) }\end{array}$ & $\begin{array}{l}\text { Czech } \\
\text { National } \\
\text { Bank } \\
\text { repo rate } \\
\text { at year- } \\
\text { end (\%) }\end{array}$ & $\begin{array}{c}\text { REER } \\
\text { (real } \\
\text { exchange } \\
\text { rate } \\
\text { deflated } \\
\text { by unit } \\
\text { labour } \\
\text { cost } \\
\text { index, } \\
2015=10 \\
0 \text { ) }\end{array}$ & $\begin{array}{c}\text { Real } \\
\text { GDP } \\
\text { growt } \\
\text { h }(\%, \\
\mathrm{y} / \mathrm{y})\end{array}$ & $\begin{array}{c}\text { Ger- } \\
\text { many } \\
\text { (bench } \\
\text { mark } \\
\text { econ- } \\
\text { omy), } \\
\text { real } \\
\text { GDP } \\
(\%, \\
\text { y/y) }\end{array}$ \\
\hline 2007 & 3.2 & -0.4 & 27.5 & 4.45 & 0.33 & 3.50 & 109 & 5.6 & 3.4 \\
\hline 2008 & 2.2 & 0.8 & 28.3 & 3.59 & 1.27 & 2.25 & 112 & 2.7 & 0.8 \\
\hline 2009 & -1.5 & 1.3 & 33.6 & 3.76 & 1.34 & 1.25 & 112.9 & -4.8 & -5.6 \\
\hline 2010 & -0.8 & -0.7 & 37.4 & 2.89 & 1.05 & 0.75 & 116.7 & 2.3 & 3.9 \\
\hline 2011 & 0.8 & -0.5 & 39.8 & 2.43 & 1.69 & 0.75 & 113.8 & 1.8 & 3.7 \\
\hline 2012 & -0.3 & -0.3 & 44.5 & 0.73 & 0.44 & 0.05 & 114.5 & -0.8 & 0.7 \\
\hline 2013 & -1.9 & -1.0 & 44.9 & 0.97 & 0.06 & 0.05 & $106.7 *$ & -0.5 & 0.6 \\
\hline 2014 & -1.3 & $0.3^{* *}$ & 42.2 & 0.20 & 0.19 & 0.05 & 101.7 & 2.7 & 2.2 \\
\hline
\end{tabular}

* The Czech National Bank started to intervene against its own currency/devaluation = positive for REER indicator; ** Fiscal policy change related to the demise of the austerity government in 2013.

Source: Czech National Bank, Czech Statistical Office, Bloomberg

How about the situation at the ZLB but with an exogenously added positive fiscal impulse at that time? The policy recommendation stemming from the model may be different in this case. We asked CNB researchers J. Brůha and J. Tonner who did an expost assessment of the monetary policy to extend the set of simulations from the model presented in their paper (see Brůha, Tonner 2017). We simulated in DSGE model an increase in government spending (in terms of government investment) of $8 \%$ yearly between 2011 and 2013. ${ }^{17}$ This would have added $0.4 \mathrm{pp}$ to GDP growth and more especially increased the inflation rate by about $0.5 \mathrm{pp}$. Hence, the inflation outlook in 2013 would not have been negative and the monetary policy reaction could have been different.

So, the fiscal restriction during 2010-2013:

(i) caused the second recession in the Czech Republic in 2012/2013, at a time when the benchmark economy - Germany - was already growing,

(ii) and may have been a trigger for the Czech National Bank to switch to unconventional Monetary Policy.

\footnotetext{
${ }^{17}$ This corresponds to a quarterly increase of about CZK 15 billion in nominal terms.
} 
Nevertheless, we have to admit that the zero lower bound is still difficult to judge with a more appropriate empirical test given that there is not enough data to split the sample between the years at the ZLB and the years away from it. There are variable lags between the implementation of policies and their economic effects. ${ }^{18}$

\section{Conclusions}

The statistician George Box (1976) famously stated that it would be very remarkable if any system existing in the real world could be exactly represented by any simple model. For such a model, there is no need to ask the question, "Is the model true?". If "truth" is to be the "whole truth," the answer must be "No." The only question of interest is, "Is the model illuminating and useful?". All models are approximations - essentially, all models are wrong (yes, even mainstream DSGE), but some are useful.

In this policy article, we identified the problem of New-Keynesian DSGE models in practice at the zero lower bound. Staying in the mainstream New-Keynesian philosophy, we derived mathematically from the IS-LM model that expansionary fiscal policy acting via higher government spending (in terms of government investment) can be an appropriate tool for reacting to a crisis in the very short run when interest rates hit the zero lower bound. This is not a call for fiscal expansion and borrowing over the entire business cycle, as we are considering only the short period of time when interest rates reach zero and there is a need for policy action.

The experience clearly shows that sometimes the right approach is to use more tools, not to rely on a single one, and also to employ common sense. Despite the fact that the IS-LM model used to be regarded as too simplistic and unable to describe the economy as a whole, the IS-LM model extended to include the zero interest rate situation offers us quite clear short-term economic policy recommendations in an ongoing economic crisis. The simplicity of the IS-LM model is conversely an advantage in this situation, as it allows us to clearly identify the impacts of the ZLB constraint on central bank rates.

The contemporary DSGE models used by central banks and ministries of finance are far more complex than the specific solution we have developed. In contrast to these DSGE models, IS-LM does not allow economists and policy makers to work with the expectations of economic agents; also, by their very nature, IS-LM-based models are models of a closed economy - they mostly ignore the reaction of the exchange rate and also finan-

\footnotetext{
${ }^{18}$ See Alesina et al. (2019) for such a discussion and for a study of nearly 200 episodes of fiscal restrictions in the rich world to understand the best way to go about it. Their empirical findings are similar to our maths: when the economy has slack, an increase in government spending is less likely to crowd out private consumption and investment, therefore it may produce an expansionary effect on output, stronger than tax cuts. Their other findings were that tax increases are more costly than spending cuts in recessions (because business confidence and private investment respond negatively to tax hikes). Austerity can sometimes be successful in a recession, but it has to remove uncertainty and stimulate demand by making customers and especially investors more optimistic about the future.
} 
cial frictions. However, DSGE models under zero lower bound conditions should not ignore the logic and flow of funds derived above and common sense.

We showed an example of a small open economy - the Czech Republic - where fiscal restriction occurred in a situation of a negative output gap, which now seems to have been a policy mistake. Restriction based on tax increases obviously caused the second recession in the Czech Republic in 2012/2013. Expansionary fiscal policy after the 2008/2009 crisis would probably have led to faster stabilisation of the Czech economy, which would have meant less pressure for monetary policy expansion using unconventional interventions against the Czech koruna. This testifies more to economic policy mistakes in general than to a failure of the CNB's DSGE models per se.

Disclosure statement: No potential conflict of interest was reported by the author.

\section{References}

ALESINA, A., FAVERO, C., GIAVAZZI, F. (2019). Austerity: When It Works and When It Doesn't. Princeton; Oxford: Princeton University Press.

ALIYEV, I., BOBKOVÁ, B., ŠTORK, Z. (2014). Extended DSGE Model of the Czech Economy. Ministry of Finance, Czech Republic, No. 1/2014.

AMBRIŠKO, R., AUGUSTA, V., HÁJKOVÁ, D., KRÁL, P., NETUŠILOVÁ, P., ŘÍKOVSKÝ, M., SOUKUP, P. (2012). Fiscal Discretion in the Czech Republic in 2001-2011: Has It Been Stabilizing? CNB Research and Policy Note 1/2012.

ANDRLE, M., HLÉDIK, T., KAMENÍK, O., VLČEK, J. (2009). Implementing the New Structural Model of the Czech National Bank. CNB Working Paper 2/2009.

BENEŠ, J., HLÉDIK, T., KUMHOF, M., VÁVRA, D. (2005). An Economy in Transition and DSGE: What the Czech National Bank's New Projection Model Needs. CNB Working Paper 12/2005.

BERNANKE, B., GERTLER, M., GILCHRIST, S. (1998). The Financial Accelerator in a Quantitative Business Cycle Framework. Working Paper 6455, National Bureau of Economic Research.

BLANCHARD, O. (2018). On the Future of Macroeconomic Models. Oxford Review of Economic Policy, 34(1-2), 43-54. DOI: 10.1093/oxrep/grx045

BOX, G. E. P. (1976). Science and Statistics. Journal of the American Statistical Association, 71, 791-799. DOI: 10.1080/01621459.1976.10480949

BRŮHA, J. (2015). Dynamics of Linear Forward-looking Structural Macroeconomic Models at the Zero Lower Bound: Do Solution Techniques Matter?, CNB WP 13/2015.

BRU゚HA, J., HLÉDIK, T. (2018). Mají DSGE modely budoucnost? - zamyšlení nad textem Oliviera Blancharda. Czech National Bank, internal report, mimeo.

BRU゚HA, J., TONNER, J. (2017). An Exchange Rate Floor as an Instrument of Monetary Policy: An Ex-post Assessment of the Czech Experience, Czech National Bank, CNB Working Paper Series 4/2017. 
BURDA, M., WYPLOSZ, C. (2013). Macroeconomics: A European Text. 6th Edition, Oxford University Press.

CAMPBELL, J., MANKIW, G. (1989). Consumption, Income and Interest Rates: Reinterpreting the Time Series Evidence. NBER Chapters, in: NBER Macroeconomics Annual 1989, Volume 4, 185-246. National Bureau of Economic Research, Inc.

CARTER, M. (2001). Foundations of Mathematical Economics. MIT Press Books, The MIT Press, edition 1, volume 1, number 0262032899, January.

CHRISTIANO, L., MOTTO, R., ROSTANGO, M. (2014). Risk Shocks. American Economic Review, 104(1), 27-65. DOI: 10.1257/aer.104.1.27

COLANDER, D. (2003). The Strange Persistence of the IS/LM Model. Paper prepared for the HOPE conference on The IS/LM Model: Its Rise, Fall and Strange Persistence. Duke University. April 25-27, 2003.

DEGRAUWE, P., GROSS, D. (2009). A New Two-Pillar Strategy for the ECB. CESifo Working Paper Series 2818, CESifo Group Munich.

FRANTA, M., HOLUB, T., KRÁL, P. KUBICOVÁ, I., ŠMÍDKOVÁ, K., VAŠÍČEK, B. (2014). The Exchange Rate as an Instrument at Zero Interest Rates: The Case of the Czech Republic. CNB Research and Policy Notes 2014/03.

GALÍ, J., LOPEZ-SALIDO, J., VALLES, J. (2007). Understanding the Effects of Government Spending on Consumption. Journal of the European Economic Association, 13(6), 227-270. DOI: 10.1162/JEEA.2007.5.1.227

HANSEN, A. H. (1949). Monetary Theory and Fiscal Policy. 1st Edition. New York: McGraw-Hill.

HICKS, J. R. (1937). Mr. Keynes and the "Classics"; A Suggested Interpretation. Econometrica, 5(2), 147-159. DOI: 10.2307/1907242

HICKS, J. R. (1976). Some Questions of Time in Economics. In Evolution, Welfare and Time in Economics.139-154.

HICKS, J. R. (1980). IS-LM: An Explanation. Journal of Post Keynesian Economics, 3(2), DOI: $10.1080 / 01603477.1980 .11489209$

IMF, MIT. (2014). Post-Crisis Fiscal Policy. Cambridge, Massachusetts: Massachusetts Institute of Technology and the International Monetary Fund. ISBN 978-0-262-02718-2.

JUSTINIANO, A., PRIMICERI, G., TAMBALOTTI, A. (2017). Empirical DSGE Models: From the Great Moderation to the Great Recession and Beyond. In DSGE Models in the Conduct of Policy: Use as Intended, edited by Refet Gürkaynak and Cédric Tille, a VoxEU.org Book, CEPR Press, April 2017.

KENNEDY, M. (2011). Background Notes on Fiscal Policy. Queen’s University.

KILEY, M. T., ROBERTS, J. M. (2017). Monetary Policy in a Low Interest Rate World. Brookings Papers on Economic Activity, BPEA Conference Drafts, March 2324, 2017. 
KOENIG, E. (2011). An IS-LM Analysis of the Zero-Bound Problem. Federal Reserve Bank of Minneapolis. Staff Papers nb. 13.

KRUGMAN, P. (2011). IS-LMentary. The New York Times, October 9, 2011.

KRUGMAN, P. (2018). Good Enough for Government Work? Macroeconomics since the Crisis. Oxford Review of Economic Policy, 34(1-2), 156-168.

MADIGAN, B., MEYER, S., REIFSCHNEIDER, D. (2008). Notes on Issues Related to the Zero Lower Bound on Nominal Interest Rates. Federal Open Market Committee.

MCCALLUM, B. T. (2000). Theoretical Analysis Regarding a Zero Lower Bound on Nominal Interest Rates. Journal of Money, Credit and Banking, 32(4), 870-904. DOI: $10.2307 / 2601148$

MERTENS, T., WILLIAMS, J. (2019). Monetary Policy Frameworks and the Effective Lower Bound on Interest Rates. Federal Reserve Bank of New York Staff Reports 877.

Oxford Review of Economic Policy (2018), Volume 34, Issue 1-2, Spring-Summer 2018. Rebuilding macroeconomic theory. https://academic.oup.com/oxrep/issue/34/1-2

PARKER, J., SOULELES, N., JOHNSON, D., MCCELLAND, R. (2013). Consumer Spending and the Economic Stimulus Payments of 2008. American Economic Review, 103(6). 2530-2553. ISSN: 0002-8282.DOI: $\underline{10.1257 / \text { aer.103.6.2530 }}$

RACHEL, L., SUMMERS, L. (2019). On Falling Neutral Real Rates, Fiscal Policy, and the Risk of Secular Stagnation. Brookings Papers on Economic Activity, forthcoming.

ROBERTSON, D. H. (1936). Some Notes on Mr. Keynes' General Theory of Interest. Quarterly Journal of Economics, 51, 168-191. DOI: 10.2307/1882506

ROMER, D. (2000). Keynesian Macroeconomics without the LM Curve. Journal of Economic Perspectives, 14(2), 149-169. DOI: 10.1257/jep.14.2.149

RYŠÁNEK, J., TONNER, J., TVRZ, S., VAŠÍČEK, O. (2012). Monetary Policy Implications of Financial Frictions in the Czech Republic. CNB Working Paper 12/2011.

TOBIN, J. (1981). Money and Finance in the Macro-Economic Process. James Tobin Prize Lecture. NobelPrize.org. Nobel Media AB 2018. Sun 7 Oct 2018.

WILLIAMS, J. (2018). DSGE Models: A Cup Half Full. VoxEU, 8 Apr 2018. 